\title{
Innovations and income inequalities - a comparative study
}

\author{
Julia Włodarczyk \\ Department of Economics, University of Economics in Katowice \\ Poland \\ julia.wlodarczyk@ue.katowice.pl
}

Abstract. Due to the complexity of relationships between innovations and income inequalities, the choice of measures to be taken in the course of their interaction is very important. This paper presents a regression analysis based on the selected measures of innovativeness (gross domestic expenditure on R\&D, number of patent applications, the Creative Economy Index), income inequalities (Gini coefficient, top 3\% and top 1\% shares of national equalized income) and various control variables retrieved mostly from the Eurostat Database for 30 countries (European Union countries, Iceland, Norway) for the

$$
\begin{array}{r}
\text { Received: } \\
\text { May, 2017 } \\
\text { 1st Revision: } \\
\text { September, 2017 } \\
\text { Accepted: } \\
\text { October, 2017 } \\
\text { DOI: } \\
\text { 10.14254/2071- }
\end{array}
$$
study period of 2005-2014. It has been found that higher gross domestic expenditure on $R \& D$ as a percentage of GDP tends to increase inequalities, while higher number of patent applications and higher value of the Creative Economy Index have the opposite effect. Besides, top income inequality is partly driven by different factors than broader measures of income inequalities.

Keywords: innovations, income inequalities, economic growth.

JEL Classification: O11, O33, D63

\section{INTRODUCTION}

Since the 1970s many countries have witnessed the increasing income inequalities in their societies. There are several potential explanations for this trend. For instance, according to (Kuznets, 1955), increasing income inequalities may be the result of structural changes. Although Kuznets concentrated on the transition from agriculture to industry and the process of urbanization (noticing that rural populations can be characterized by lower average incomes and lower income inequalities, so an increasing share of urban population implies increasing income inequalities), his observations may also apply to the transition from industry to services, including financial ones. Similarly, transition from a centrally planned to a market-based economy meant significant increases in income inequalities for many countries that experienced this transition since late 1980s - early 1990s (Włodarczyk, 2013).

Currently, the literature identifies several other causes for income inequality such as skill-biased technological change, international trade and ongoing globalization, immigration, education, institutions 
and gender inequality with the first factor perceived as the most prominent one (Kierzenkowski \& Koske, 2013; Lemieux, 2008; Aghion et al., 1999).

From the traditional point of view, a new technology raises productivity and wages, both for lowand high-skilled workers, so it may either increase, or decrease income inequalities. Skill-biased technological change increases inequalities, but it also increases the relative demand for high-skilled workers creating incentives to achieve higher educational attainment. Naturally, greater supply of highskilled workers translates into reduction of inequalities. This demand and supply framework was successful in explaining changes in the US wage structure until the 1990s (Katz \& Murphy, 1992), but failed to explain later developments such as declining real wages at the lower end of income distribution and wage polarization as well as domestic labor substitution either by capital (e.g., computers) or by foreign labor due to offshoring (Acemoglu \& Autor, 2010). These shortcomings were addressed by subsequent literature. In particular, Autor et al. (2003) emphasized the role of tasks performed in a job and distinguished routine tasks that can be substituted by computers or machines and non-routine tasks that are usually complemented by new technologies. When computerization displaces medium-skilled workers that cannot substitute high-skilled workers, wage polarization is likely to increase.

Furthermore, widening inequalities may result from the fact that implementation of new technologies can be usually done by skilled labor only, so that skilled workers find employment in new sectors and earn higher wages (the so-called skill premium), while unskilled workers remain at old sectors with prevailing wages. Some workers are able to adapt faster to leading-edge technologies several periods in a row and thus obtain an additional premium (Aghion, 2002). However, as suggested by (Antonelli \& Gehringer, 2017), inspired by the Schumpeterian growth theory, if new vintages of technological innovation destroy the competitive advantage of incumbents and reduce the duration of monopolistic rents, the faster is the rate of technological change, the faster would be the reduction of income inequalities. The Schumpeterian concept of creative destruction (Schumpeter, 1947) can be also useful for explaining top income inequality. In particular, entrepreneurs exert effort to generate exponential growth in their incomes, but creative destruction by outside innovators hampers this expansion, thus, top incomes are likely to follow the logic of Pareto distribution (Jones \& Kim, 2017).

The main idea of the paper is that due to complexity of relationships between innovations and income inequalities, the choice of measures is very important. It is possible that some measures of innovation may be positively correlated with income inequalities, while others will exhibit a negative relationship.

The aim of the paper is to compare empirically the character of this nexus between innovations and income inequalities for different measures of both phenomena.

This paper is closely related to (Antonelli \& Gehringer, 2017) who used the data on the United States, Canada, the European Union countries and also BRIC members for the years 1995-2011 to show that innovation (measured by patent applications weighted by the size of an economy) is a major factor reducing income inequalities measured via the Gini coefficient. Following the recent interest in top income inequality (Piketty \& Saez, 2003; Atkinson et al., 2011) and the possibility that income inequalities have been only widening in the recent decades at least partly due to growing concentration of income among the top earners, the analysis is conducted also for two measures depicting the share of top income percentiles. This brings the paper closer to (Aghion et al., 2015) who used the cross-state panel data over the period 1975-2010 for the United States and demonstrated that top income inequality is driven by innovation, but innovation does not increase broader measures of inequalities.

The novel aspect of this paper is the use of a new synthetic measure of innovativeness, namely, the Creative Economy Index (Żelazny \& Pietrucha, 2017) along with other well-established measures of innovativeness (such as gross domestic expenditure on $\mathrm{R} \& \mathrm{D}$ and the number of patent applications). 
The remainder of the paper is structured as follows. Section 2 describes data and methodology used in the conducted analysis, Section 3 presents the results of panel regressions, and Section 4 concludes.

\section{DATA AND METHODOLOGY}

The analysis is confined to countries for which the values of the Creative Economy Index (CEI) were available. CEI has been calculated for 34 countries (European Union countries, Turkey, Iceland, Norway, Switzerland, Serbia and Macedonia) over the period 2005-2014. Therefore, annual data covering this period were collected for three measures of income inequalities (the Gini coefficient, top 3\% and top 1\% share of national equivalized income), three measures of innovativeness (gross domestic expenditure on $\mathrm{R} \& \mathrm{D}$, number of patent applications and the Creative Economy Index) and several control variables (see Table 1). Due to unavailability of some data Turkey, Switzerland, Macedonia and Serbia were excluded from the sample. In case of remaining countries a few missing values were replaced with the earliest (latest) available observation or filled by linear interpolation.

The choice of control variables mostly reflects a standard practice. For instance, Aghion et al. (2015) control for the size of the government sector and financial sector, GDP per capita and the growth of total population, and suggest inclusion of data on marginal tax rates as taxation may affect both incentives to innovate and the top 1\% income share. Due to the lack of data on marginal income tax rates, the analysis is based on total tax rates as a percentage of commercial profits which may explain some cross-country differences, but not necessarily the behavior of top income shares. Inclusion of inflation rate is motivated by the relationship between inflation and income inequalities discussed by Albanesi (2007). This list is supplemented with the unemployment rate, the percentage of working-age population with tertiary education (which was traditionally supposed to decrease income inequalities) and two variables referring to financial and trade openness to control for the impact of globalization.

As reported in table 2 in the appendix, all measures of income inequalities changed in the same direction in most countries with the exception of Estonia, Hungary (where increasing values of the Gini coefficient were observed along with decreasing values of top income inequality), and Lithuania (where an opposite tendency occurred). Gross domestic expenditure on R\&D relative to GDP rose in the majority of countries over the analyzed period (with the most outstanding exception of Iceland where its value dropped from 2.7 in 2005 to 1.9 in 2014), but the other two measures of innovativeness changed in the same direction only in case of seven countries. Altogether, there was no universal pattern in terms of the relationship analyzed in the paper. There were countries where income inequalities and innovativeness were both increasing (e.g. Austria, Bulgaria, and Slovenia), both decreasing (Iceland), or the changes were in opposite directions (Czech Republic) for all or for some of the measures over 2005-2014. It is also worth mentioning that despite some country-specific differences, there is a common framework concerning innovation policy. All the countries belong to the European Economic Area with Research and Innovation constituting one of the core objectives of the Europe 2020 Strategy for smart, sustainable and inclusive growth.

In general, the sample used in the empirical analysis is a balanced panel of 30 states (European Union countries, Iceland and Norway) and a total of 300 observations (30 states over 10 years). For each combination of measures of innovations and income inequalities with all the control variables the Breusch-Pagan LM test was conducted. In each case the p-value was very close to zero providing evidence of significant differences across countries. Next, to decide on the character of individual effects (fixed or random) the Hausman test was run. In five cases (all the regressions including the gini and/or gerd variable) the null hypothesis that there is no correlation between regressors and effects (implying that both fixed and random effect estimators are consistent, but fixed effect estimator is inefficient) was rejected at the 0.05 level of significance. For the remaining four cases this hypothesis could not be rejected. 
Table 1

Description of the dataset

\begin{tabular}{|c|c|c|c|c|c|}
\hline $\begin{array}{l}\text { Variable } \\
\text { name }\end{array}$ & Description (source) & Mean & St. dev. & Min. & Max. \\
\hline \multicolumn{6}{|c|}{ Measures of income inequalities } \\
\hline gini & $\begin{array}{l}\text { Gini coefficient of equivalized disposable income } \\
\text { (Eurostat, 2017) }\end{array}$ & 29.53 & 4.01 & 22.50 & 38.90 \\
\hline top3 & $\begin{array}{l}\text { Share of national equivalized income attributed to top } 3 \\
\text { percentiles (Eurostat, 2017) }\end{array}$ & 10.16 & 1.46 & 7.40 & 15.00 \\
\hline top1 & $\begin{array}{l}\text { Share of national equivalized income attributed to the } \\
\text { highest percentile (Eurostat, 2017) }\end{array}$ & 4.87 & 1.00 & 3.00 & 10.00 \\
\hline \multicolumn{6}{|c|}{ Measures of innovativeness } \\
\hline gerd & $\begin{array}{l}\text { Gross domestic expenditure on R\&D as a percentage } \\
\text { of GDP (Eurostat, 2017) }\end{array}$ & 1.53 & 0.87 & 0.37 & 3.75 \\
\hline patents & $\begin{array}{l}\text { Patent applications to the EPO by priority year per } \\
\text { thousand inhabitants (Eurostat, 2017) }\end{array}$ & 87.00 & 95.32 & 0.80 & 349.36 \\
\hline CEI & Creative Economy Index (Żelazny \& Pietrucha, 2017) & 0.07 & 0.67 & -1.26 & 1.22 \\
\hline \multicolumn{6}{|c|}{ Control variables } \\
\hline GDPpc & $\begin{array}{l}\text { GDP per capita in PPS, index (EU28=100) (Eurostat, } \\
2017)\end{array}$ & 100.56 & 42.74 & 34.00 & 266.00 \\
\hline$s q G D P p c / 1000$ & $\begin{array}{l}\text { GDP per capita in PPS, squared and divided by } 1000 \\
\text { (Eurostat, 2017) }\end{array}$ & 11.93 & 11.95 & 1.16 & 70.76 \\
\hline gov & $\begin{array}{l}\text { General government final consumption expenditure as } \\
\text { a percentage of GDP (Eurostat, 2017) }\end{array}$ & 20.14 & 2.80 & 14.10 & 27.90 \\
\hline $\operatorname{tax}$ & $\begin{array}{l}\text { Total tax rate as a percentage of commercial profits } \\
\text { (World Bank, 2017) }\end{array}$ & 42.69 & 12.89 & 18.40 & 76.70 \\
\hline pop_growth & Crude rate of total population change (Eurostat, 2017) & 3.01 & 8.77 & -28.90 & 30.90 \\
\hline unemp & $\begin{array}{l}\text { Unemployment as a percentage of active population } \\
\text { (Eurostat, 2017) }\end{array}$ & 8.72 & 4.32 & 2.30 & 27.50 \\
\hline tert & $\begin{array}{l}\text { Population with tertiary education (level 5-8) as a } \\
\text { percentage of working age population (15-64 years) } \\
\text { (Eurostat, 2017) }\end{array}$ & 83.32 & 3.90 & 67.60 & 92.20 \\
\hline kaopen & $\begin{array}{l}\text { Measure of financial openness: Chinn-Ito index (Chinn } \\
\text { \& Ito, 2016; explained in Chinn \& Ito, 2006) }\end{array}$ & 2.05 & 0.76 & -1.19 & 2.39 \\
\hline tr_open & $\begin{array}{l}\text { Measure of trade openness calculated as the sum of } \\
\text { exports and imports as a percentage of GDP (Eurostat, } \\
\text { 2017) }\end{array}$ & 1.16 & 0.64 & 0.46 & 3.85 \\
\hline infl & $\begin{array}{l}\text { All-items HICP, annual average rate of change } \\
\text { (Eurostat, 2017) }\end{array}$ & 2.66 & 2.35 & -1.70 & 16.30 \\
\hline $\mathrm{fin} / 1000$ & $\begin{array}{l}\text { Total financial assets as a percentage of GDP divided } \\
\text { by } 1000 \text { (Eurostat, 2017, for Iceland: Statistics Iceland, } \\
2017 \text { ) }\end{array}$ & 1.00 & 2.61 & 0.04 & 18.45 \\
\hline
\end{tabular}

Source: Author's elaboration.

Conducted analysis comes down to the estimation of a series of panel models including individual effects (fixed or random, dependent on the result of the Hausman test), regressing a measure of income inequalities in country $i$ at time $t$, against a measure of innovativeness and a vector of control variables. For each combination of analyzed measures three models are estimated: (1) without time dummies, (2) with all time dummies, (3) with significant control variables and time dummies. 


\section{MAIN RESULTS}

Main estimation results are reported in the appendix (see Table 3-5).

As expected, conducted calculations demonstrate that the character of the relationship between innovation and income inequalities depends on the choice of the measure of innovativeness. In general, higher gross domestic expenditure on R\&D as a percentage of GDP tends to increase inequalities, while a higher number of patent applications or a higher value of the Creative Economy Index has an opposite effect (however, for combinations: gini and patents as well as for top 1 and CEI this relationship is not statistically significant in any specification). The strongest negative relationship is found for gini and CEI (observed in all three model specifications), implying that countries with better institutions supporting innovativeness are also more equal in terms of income distribution.

There is only one universal factor driving inequality in all specifications, namely the fraction of working age population with tertiary education. This confirms that a greater supply of high-skilled workers may not decrease income inequalities. Also a higher unemployment rate and a greater financial openness imply higher inequalities in most cases, but the impact of other factors on income inequalities depends on the choice of inequality measure (this contrast is especially pronounced between gini and narrow measures: top 3 and top 1 ).

As far as Gini coefficient is concerned, both the population growth rate and the level of GDP per capita in PPS have negative impact on its value (in the latter case the relationship is in fact nonlinear as squared values of GDP per capita had positive coefficients). For GDP per capita and financial openness conducted analysis confirms the results of Antonelli \& Gehringer (2017), however, in the case analyzed here neither trade openness nor government expenditures play a significant role, although the signs of their coefficients are the same.

The main drivers of top income inequality are inflation and total financial assets, while trade openness tends to mitigate this phenomenon. Contrary to Aghion et al. (2015), no evidence is found for increased top income inequality to be driven by innovation, however, this result may be related to the specificity of the U.S. economy. Besides, as in Aghion et al. (2015), the negative relationship with GDP per capita seems to be weak at best, population growth plays an insignificant role (with a negative sign), while government expenditures decrease inequalities, but are often insignificant. Surprisingly, higher tax rates decrease top income inequality only in case of two models.

Obtained results are also similar to those of Jaumotte et al. (2013) who find a positive impact of financial globalization on income inequalities, negative for trade openness, positive for technology measured by the share of ICT in total capital stock, and a positive effect for population share with at least secondary education (albeit statistically insignificant). Furthermore, Peters and Volwahsen (2017) demonstrate positive impact of ICT investment as a percentage of total capital stock formation and unemployment rate on income inequalities, but report mixed results for financial openness.

Finally, the aim of including of time dummies was inter alia to capture the effects of the global financial crisis on income inequalities. However, in most specifications a significant decrease in income inequalities is observed in the years 2010, 2011 and 2012 (with 2005 as the reference year) which is the period of unfolding of the sovereign debt crisis in Europe.

\section{CONCLUSIONS}

On the whole, there is no single mechanism translating innovations into income inequalities. It is rather a dynamic interplay between capital and labor, their quality and quantity, their substitutability and complementarity, further complicated by measurement issues.

Empirical exercise conducted in this paper demonstrates that innovation can be the factor determining the scale of income inequalities. As already pointed by Jaumotte et al. (2013), innovation can 
have a potentially greater impact on income inequalities than globalization, because of two opposite pressures exerted by financial globalization and trade openness.

Different results obtained for different measures of innovativeness motivate to analyze various kinds of innovation and possibly include complementary measures of innovation in model specifications. For instance, as noted by Iacopetta (2008) faster technological change may increase income inequalities if it takes a form of product improvements, but cost-reducing innovations are more likely to decrease them.

The problem how to disentangle innovations reducing and increasing inequalities seems to be of particular interest for policymakers. Policy recommendations usually depend on chosen priorities. If the goal is the most efficient use of budget funds, the government may e.g. increase its expenditures on research and development (with income inequalities as a potential side effect). However, if the priority is given to low income inequalities, the government may consider implementing other, preferably more inclusive, instruments of innovation policy.

\section{ACKNOWLEDGEMENT}

The author is grateful to an anonymous reviewer for helpful comments. All remaining errors are the sole responsibility of the author.

\section{REFERENCES}

Acemoglu, D., \& Autor, D. (2010). Skills, Tasks and Technologies: Implications for Employment and Earnings, in: Ashenfelter, O., \& Card, D. (eds.): Handbook of Labor Economics, Vol. 4B, Elsevier, 1043-1171. doi:10.1016/S0169-7218(11)02410-5

Aghion, P. (2002). Schumpeterian growth theory and the dynamics of income inequality. Econometrica, 70(3), 855-882.

Aghion, P., Akcigit, U., Bergeaud, A., Blundell, R., \& Hémous, D. (2015). Innovation and top income inequality. INSEAD Working Paper Series, 2015/50/EPS.

Aghion, P., Caroli, E., \& García-Peñalosa, C. (1999). Inequality and Economic Growth: The Perspective of the New Growth Theories. Journal of Economic Literature, 37(4), 1615-1660. doi:10.1257/jel.37.4.1615

Albanesi, S. (2007). Inflation and inequality. Journal of Monetary Economics, 54, 1088-1114.

Antonelli, C., \& Gehringer, A. (2017). Technological change, rent and income inequalities: A Schumpeterian approach. Technological Forecasting and Social Change, 115, 85-98. doi: 10.1016/j.techfore.2016.09.023

Atkinson, A. B., Piketty, T., \& Saez, E. (2011). Top incomes in the long run of history. Journal of Economic Literature, 49(1), 3-71. doi:10.1257/jel.49.1.3

Autor, D. H., Levy, F., \& Murnane, R. J. (2003). The Skill Content of Recent Technological Change: An Empirical Exploration. The Quarterly Journal of Economics, 118(4), 1279-1333. doi:10.1162/003355303322552801

Chinn, M. D., \& Ito, H. (2006). What Matters for Financial Development? Capital Controls, Institutions, and Interactions. Journal of Development Economics, 81(1), 163-192.

Chinn, M. D., \& Ito, H. (2016). Retrieved from http://web.pdx.edu/ ito/Chinn-Ito website.htm.

Eurostat (2017). Retrieved from http:/ / ec.europa.eu/eurostat/data/database.

Iacopetta, M. (2008). Technological progress and inequality: an ambiguous relationship. Journal of Evolutionary Economics, 18, 455-475. doi:10.1007/s00191-008-0100-1

Jaumotte, F., Lall, S., \& Papageorgiou, Ch. (2013). Rising Income Inequality: Technology, or Trade and Financial Globalization? IMF Economic Review, 61(2), 271-309.

Jones, C. I., \& Kim J. (2017). A Schumpeterian Model of Top Income Inequality. Journal of Political Economy, forthcoming.

Katz, L. F., \& Murphy, K. M. (1992). Changes in Relative Wages, 1963-1987: Supply and Demand Factors. The Quarterly Journal of Economics, 107(1), 35-78.

Kierzenkowski, R., \& Koske, I. (2013). The Drivers Of Labor Income Inequality - A Literature Review, Journal of International Commerce, Economics and Policy, 4(01), 1-32. doi:10.1142/S179399331350004X

Kuznets, S. (1955). Economic growth and income inequality. The American Economic Review, 45(1), 1-28. 
Lemieux, T. (2008). The changing nature of wage inequality. Journal of Population Economics, 21(1), 21-48.

Peters, H., \& Volwahsen, M. (2017). Rising Income Inequality: Do Not Draw the Obvious Conclusions. Intereconomics, 52(2) 111-118.

Piketty, T., \& Saez, E. (2003). Income inequality in the United States, 1913-1998. The Quarterly Journal of Economics, 118(1), 1-39.

Schumpeter, J. A. (1947). The Creative Response in Economic History. The Journal of Economic History, 7(2), 149-159.

Statistics Iceland (2017). Retrieved from http://statice.is/statistics/economy/national-accounts/financial-accounts/

Włodarczyk, J. (2013). Nierówności dochodowe w Polsce według rozkładów Pareto i Boltzmanna-Gibbsa. Studia Ekonomiczne, 130, 76-87.

World Bank (2017). Doing Business project. Retrieved from http://www.doingbusiness.org.

Żelazny, R., \& Pietrucha, J. (2017). Measuring innovation and institution. Equilibrium. Quarterly Journal of Economics and Economic Policy, 12(1), 43-62. doi: 10.24136/eq.v12i1.3 


\section{APPENDIX}

Table 2

Income inequalities and innovation at a country level

\begin{tabular}{|c|c|c|c|c|c|c|c|c|c|c|c|c|}
\hline \multirow{2}{*}{ Country } & \multicolumn{2}{|c|}{ gini } & \multicolumn{2}{|c|}{ top3 } & \multicolumn{2}{|c|}{ top1 } & \multicolumn{2}{|c|}{ gerd } & \multicolumn{2}{|c|}{ patents } & \multicolumn{2}{|c|}{$C E I$} \\
\hline & 2005 & 2014 & 2005 & 2014 & 2005 & 2014 & 2005 & 2014 & 2005 & 2014 & 2005 & 2014 \\
\hline Belgium & 28.0 & 25.9 & 11.3 & 8.2 & 7.2 & 3.7 & 1.8 & 2.5 & 1.45 & 1.37 & 0.328 & 0.399 \\
\hline Bulgaria & 31.2 & 35.4 & 10.5 & 12.1 & 5.2 & 5.9 & 0.4 & 0.8 & 0.03 & 0.07 & -1.047 & -0.964 \\
\hline Czech Republic & 26.0 & 25.1 & 9.8 & 9.5 & 4.7 & 4.4 & 1.2 & 2.0 & 0.11 & 0.25 & -0.355 & -0.277 \\
\hline Denmark & 23.9 & 27.7 & 8.1 & 10.8 & 3.8 & 6.0 & 2.4 & 3.1 & 2.20 & 2.44 & 1.148 & 0.944 \\
\hline Germany & 26.1 & 30.7 & 9.7 & 10.5 & 4.9 & 5.3 & 2.4 & 2.9 & 2.92 & 2.56 & 0.652 & 0.621 \\
\hline Estonia & 34.1 & 35.6 & 10.9 & 10.5 & 4.9 & 4.2 & 0.9 & 1.4 & 0.05 & 0.10 & 0.019 & 0.268 \\
\hline Ireland & 31.9 & 30.8 & 12.0 & 10.6 & 6.7 & 4.9 & 1.2 & 1.5 & 0.67 & 0.65 & 0.590 & 0.748 \\
\hline Greece & 33.2 & 34.5 & 10.6 & 11.6 & 4.7 & 6.0 & 0.6 & 0.8 & 0.10 & 0.11 & -0.524 & -0.765 \\
\hline Spain & 32.2 & 34.7 & 9.8 & 10.0 & 4.3 & 4.3 & 1.1 & 1.2 & 0.32 & 0.33 & -0.094 & -0.329 \\
\hline France & 27.7 & 29.2 & 9.9 & 11.5 & 4.5 & 5.7 & 2.0 & 2.3 & 1.34 & 1.38 & 0.280 & 0.248 \\
\hline Croatia & 31.6 & 30.2 & 9.1 & 8.7 & 4.0 & 3.6 & 0.9 & 0.8 & 0.08 & 0.03 & -0.930 & -0.771 \\
\hline Italy & 32.7 & 32.4 & 11.6 & 10.5 & 5.7 & 4.8 & 1.1 & 1.3 & 0.85 & 0.70 & -0.426 & -0.623 \\
\hline Cyprus & 28.7 & 34.8 & 9.9 & 15.0 & 4.9 & 8.4 & 0.4 & 0.5 & 0.23 & 0.08 & -0.076 & -0.142 \\
\hline Latvia & 36.2 & 35.5 & 12.7 & 11.2 & 6.4 & 5.0 & 0.5 & 0.7 & 0.08 & 0.32 & -0.559 & -0.445 \\
\hline Lithuania & 36.3 & 35.0 & 11.5 & 11.6 & 4.9 & 5.0 & 0.8 & 1.0 & 0.03 & 0.17 & -0.507 & -0.351 \\
\hline Luxembourg & 26.5 & 28.7 & 8.7 & 9.1 & 3.9 & 4.2 & 1.6 & 1.3 & 2.13 & 1.09 & 0.674 & 0.770 \\
\hline Hungary & 27.6 & 28.6 & 10.7 & 10.1 & 5.6 & 4.8 & 0.9 & 1.4 & 0.13 & 0.23 & -0.356 & -0.591 \\
\hline Malta & 27.0 & 27.7 & 8.3 & 9.0 & 3.5 & 4.1 & 0.5 & 0.8 & 0.28 & 0.10 & -0.133 & -0.058 \\
\hline Netherlands & 26.9 & 26.2 & 9.8 & 9.2 & 5.0 & 4.3 & 1.8 & 2.0 & 2.15 & 2.05 & 0.843 & 0.937 \\
\hline Austria & 26.3 & 27.6 & 9.3 & 9.8 & 4.2 & 4.9 & 2.4 & 3.0 & 1.86 & 2.30 & 0.655 & 0.510 \\
\hline Poland & 35.6 & 30.8 & 12.0 & 10.1 & 5.7 & 4.6 & 0.6 & 0.9 & 0.03 & 0.16 & -0.695 & -0.368 \\
\hline Portugal & 38.1 & 34.5 & 13.7 & 11.0 & 6.4 & 5.0 & 0.8 & 1.3 & 0.12 & 0.12 & -0.090 & -0.090 \\
\hline Romania & 38.3 & 34.7 & 12.7 & 9.9 & 6.0 & 4.5 & 0.4 & 0.4 & 0.01 & 0.05 & -1.257 & -0.804 \\
\hline Slovenia & 23.8 & 25.0 & 7.7 & 8.0 & 3.3 & 3.4 & 1.4 & 2.4 & 0.54 & 0.66 & -0.305 & -0.356 \\
\hline Slovakia & 26.2 & 26.1 & 9.5 & 9.1 & 4.8 & 4.5 & 0.5 & 0.9 & 0.06 & 0.09 & -0.511 & -0.621 \\
\hline Finland & 26.0 & 25.6 & 10.1 & 9.1 & 5.4 & 4.3 & 3.3 & 3.2 & 2.56 & 3.40 & 1.054 & 1.107 \\
\hline Sweden & 23.4 & 25.4 & 8.0 & 8.2 & 3.6 & 3.7 & 3.4 & 3.2 & 2.71 & 3.49 & 0.954 & 0.969 \\
\hline United Kingdom & 34.6 & 31.6 & 12.9 & 10.9 & 6.8 & 5.3 & 1.6 & 1.7 & 0.94 & 0.83 & 0.724 & 0.755 \\
\hline Iceland & 25.1 & 22.7 & 10.2 & 8.3 & 5.4 & 3.9 & 2.7 & 1.9 & 1.13 & 0.98 & 0.886 & 0.454 \\
\hline Norway & 28.2 & 23.5 & 14.3 & 8.4 & 10.0 & 4.1 & 1.5 & 1.7 & 1.08 & 0.94 & 0.693 & 0.729 \\
\hline
\end{tabular}

Source: Author's elaboration based on Eurostat data (2017) and (Żelazny and Pietrucha, 2017). 
Table $3 a$

Estimation of panel regressions with fixed effects. Dependent variable: Gini coefficient. Measure of innovativeness: Gross domestic expenditure on R\&D as a percentage of GDP

\begin{tabular}{|c|c|c|c|c|c|c|}
\hline \multirow{2}{*}{ Model } & \multicolumn{2}{|c|}{ (1) } & \multicolumn{2}{|c|}{ (2) } & \multicolumn{2}{|c|}{ (3) } \\
\hline & coeff. & st. error & coeff. & st. error & coeff. & st. error \\
\hline gerd & 1.025 & 0.635 & $1.160 * *$ & 0.515 & 0.663 & 0.628 \\
\hline const. & $18.343^{* * *}$ & 6.835 & $15.407 * *$ & 6.763 & $23.242^{* * *}$ & 4.895 \\
\hline GDPpc & $-0.129 * *$ & 0.061 & $-0.104 *$ & 0.057 & $-0.152^{* * *}$ & 0.052 \\
\hline sqGDPpc/1000 & $0.487 *$ & 0.249 & $0.440^{* *}$ & 0.222 & $0.606^{* * *}$ & 0.200 \\
\hline gov & -0.151 & 0.126 & -0.046 & 0.158 & & \\
\hline $\operatorname{tax}$ & -0.032 & 0.025 & -0.057 & 0.036 & & \\
\hline pop_growth & $-0.074 * *$ & 0.030 & $-0.075^{* * *}$ & 0.028 & $-0.086^{* * *}$ & 0.030 \\
\hline unemp & 0.095 & 0.063 & $0.120^{* *}$ & 0.052 & & \\
\hline tert & $0.241^{* * *}$ & 0.081 & $0.231^{* * *}$ & 0.087 & $0.143^{* * *}$ & 0.051 \\
\hline kaopen & $0.640^{* * *}$ & 0.201 & $0.729 * * *$ & 0.194 & $0.703^{* * *} *$ & 0.267 \\
\hline tr_open & -1.168 & 1.178 & -0.640 & 1.329 & & \\
\hline infl & 0.039 & 0.068 & 0.108 & 0.070 & & \\
\hline fin $/ 1000$ & 0.421 & 0.357 & 0.388 & 0.324 & & \\
\hline time dummies & \multicolumn{2}{|c|}{ No } & \multicolumn{2}{|c|}{ Yes - all } & \multicolumn{2}{|c|}{$\begin{array}{l}\text { Yes - for years 2010, } 2011 \text { and } \\
2012\end{array}$} \\
\hline $\mathrm{LSDV} \mathrm{R}^{2}$ & & 0.914 & & 0.920 & & 0.913 \\
\hline Within $\mathrm{R}^{2}$ & & 0.177 & & 0.233 & & 0.166 \\
\hline $\mathrm{BIC}$ & & 1188.059 & & 1218.360 & & 1174.751 \\
\hline AIC & & 1032.500 & & 1029.468 & & 1030.304 \\
\hline
\end{tabular}

Table 3b

Estimation of panel regressions with fixed effects. Dependent variable: Gini coefficient. Measure of innovativeness: Patent applications to the EPO by priority year per ten thousand inhabitants

\begin{tabular}{|c|c|c|c|c|c|c|}
\hline \multirow{2}{*}{ Model } & \multicolumn{2}{|c|}{ (1) } & \multicolumn{2}{|c|}{ (2) } & \multicolumn{2}{|c|}{ (3) } \\
\hline & coeff. & st. error & coeff. & st. error & coeff. & st. error \\
\hline patents & 0.020 & 0.680 & -0.496 & 0.827 & $-2.81 e-05$ & $7.26 \mathrm{e}-05$ \\
\hline const. & $19.487 * * *$ & 7.465 & $16.909^{* *}$ & 7.417 & $15.775^{* *}$ & 7.361 \\
\hline GDPpc & $-0.114 *$ & 0.068 & -0.088 & 0.066 & $-0.109 *$ & 0.057 \\
\hline sqGDPpc/1000 & $0.458^{*}$ & 0.274 & 0.396 & 0.258 & $0.477^{* *}$ & 0.240 \\
\hline gov & -0.087 & 0.123 & 0.010 & 0.158 & & \\
\hline $\operatorname{tax}$ & -0.037 & 0.031 & -0.059 & 0.041 & & \\
\hline pop_growth & $-0.075^{* *}$ & 0.030 & $-0.075^{* * *}$ & 0.028 & $-0.075^{* *}$ & 0.031 \\
\hline unemp & 0.091 & 0.064 & $0.117^{* *}$ & 0.055 & $0.104^{*}$ & 0.054 \\
\hline tert & $0.212^{* * *}$ & 0.082 & $0.207^{* *}$ & 0.086 & $0.206^{* *}$ & 0.080 \\
\hline kaopen & $0.692 * * *$ & 0.253 & $0.813^{* * *}$ & 0.242 & $0.753^{* * *}$ & 0.270 \\
\hline tr_open & -0.613 & 1.145 & -0.193 & 1.273 & & \\
\hline infl & 0.040 & 0.076 & 0.115 & 0.079 & & \\
\hline fin/1000 & 0.299 & 0.404 & 0.165 & 0.379 & & \\
\hline time dummies & \multicolumn{2}{|c|}{ No } & \multicolumn{2}{|c|}{ Yes - all } & \multicolumn{2}{|c|}{$\begin{array}{l}\text { Yes - for years 2010, } 2011 \text { and } \\
2012\end{array}$} \\
\hline LSDV R $^{2}$ & & 0.912 & & 0.918 & & 0.913 \\
\hline Within $\mathrm{R}^{2}$ & & 0.161 & & 0.214 & & 0.165 \\
\hline BIC & & 1193.886 & & 1225.419 & & 1180.783 \\
\hline AIC & & 1038.327 & & 1036.526 & & 1032.631 \\
\hline
\end{tabular}


Table 3c

Estimation of panel regressions with fixed effects. Dependent variable: Gini coefficient. Measure of innovativeness: the Creative Economy Index

\begin{tabular}{|c|c|c|c|c|c|c|}
\hline \multirow{2}{*}{ Model } & \multicolumn{2}{|c|}{ (1) } & \multicolumn{2}{|c|}{ (2) } & \multicolumn{2}{|c|}{ (3) } \\
\hline & coeff. & st. error & coeff. & st. error & coeff. & st. error \\
\hline CEI & $-2.527 * *$ & 1.182 & $-2.319 *$ & 1.202 & $-3.249 * *$ & 1.455 \\
\hline const. & $15.690 * *$ & 7.298 & $13.280^{*}$ & 7.201 & 7.302 & 6.717 \\
\hline GDPpc & -0.075 & 0.055 & -0.054 & 0.054 & & \\
\hline sqGDPpc/1000 & 0.323 & 0.210 & 0.292 & 0.191 & & \\
\hline gov & -0.087 & 0.122 & 0.011 & 0.156 & & \\
\hline $\operatorname{tax}$ & -0.035 & 0.031 & -0.056 & 0.042 & & \\
\hline pop_growth & $-0.072^{* *}$ & 0.029 & $-0.073^{* * *}$ & 0.027 & $-0.067 * *$ & 0.034 \\
\hline unemp & 0.094 & 0.063 & $0.119^{* *}$ & 0.055 & $0.110^{* *}$ & 0.053 \\
\hline tert & $0.227 * * *$ & 0.074 & $0.216^{* * *}$ & 0.078 & $0.235^{* * *}$ & 0.076 \\
\hline kaopen & $0.813^{* * *}$ & 0.257 & $0.897 * * *$ & 0.239 & $0.841 * * *$ & 0.257 \\
\hline tr_open & -0.747 & 1.110 & -0.248 & 1.229 & & \\
\hline infl & 0.044 & 0.076 & 0.112 & 0.082 & & \\
\hline fin/1000 & 0.441 & 0.339 & 0.371 & 0.331 & $0.548^{* *}$ & 0.231 \\
\hline time dummies & \multicolumn{2}{|c|}{ No } & \multicolumn{2}{|c|}{ Yes - all } & \multicolumn{2}{|c|}{$\begin{array}{l}\text { Yes - for years 2010, } 2011 \text { and } \\
2012\end{array}$} \\
\hline $\mathrm{LSDV} \mathrm{R}^{2}$ & & 0.912 & & 0.919 & & 0.913 \\
\hline Within $\mathrm{R}^{2}$ & & 0.161 & & 0.226 & & 0.171 \\
\hline BIC & & 1193.886 & & 1221.078 & & 1173.023 \\
\hline AIC & & 1038.327 & & 1032.185 & & 1028.575 \\
\hline
\end{tabular}

Table $4 a$

Estimation of panel regressions with fixed effects. Dependent variable: Share of national equivalized income attributed to top 3 percentiles. Measure of innovativeness: Gross domestic expenditure on R\&D as a percentage of GDP

\begin{tabular}{|c|c|c|c|c|c|c|}
\hline \multirow{2}{*}{ Model } & \multicolumn{2}{|c|}{ (1) } & \multicolumn{2}{|c|}{ (2) } & \multicolumn{2}{|c|}{ (3) } \\
\hline & coeff. & st. error & coeff. & st. error & coeff. & st. error \\
\hline gerd & 0.626 & 0.406 & $0.767 * *$ & 0.317 & 0.445 & 0.413 \\
\hline const. & 1.860 & 5.186 & 0.918 & 5.086 & -1.476 & 4.984 \\
\hline GDPpc & $-0.078^{* *}$ & 0.036 & $-0.061^{*}$ & 0.034 & $-0.076^{* *}$ & 0.032 \\
\hline sqGDPpc/1000 & 0.230 & 0.146 & 0.208 & 0.127 & $0.223^{*}$ & 0.114 \\
\hline gov & $-0.161 *$ & 0.092 & -0.092 & 0.098 & & \\
\hline $\operatorname{tax}$ & -0.014 & 0.014 & $-0.040^{*}$ & 0.023 & & \\
\hline pop_growth & $-0.042 *$ & 0.022 & $-0.040 *$ & 0.021 & & \\
\hline unemp & $0.067^{* *}$ & 0.033 & 0.019 & 0.148 & $0.111 * * *$ & 0.034 \\
\hline tert & $0.194 * * *$ & 0.043 & $0.081 * * *$ & 0.029 & $0.172^{* * * *}$ & 0.050 \\
\hline kaopen & $0.303^{*}$ & 0.171 & $0.167^{* *}$ & 0.066 & $0.284^{*}$ & 0.170 \\
\hline tr_open & -1.233 & 0.885 & $0.325^{* *}$ & 0.147 & & \\
\hline infl & 0.059 & 0.042 & -0.295 & 0.939 & $0.093^{*}$ & 0.055 \\
\hline fin/1000 & 0.288 & 0.247 & $0.098^{* *}$ & 0.041 & & \\
\hline time dummies & \multicolumn{2}{|c|}{ No } & \multicolumn{2}{|c|}{ Yes - all } & \multicolumn{2}{|c|}{$\begin{array}{l}\text { Yes - for years } 2010,2011 \text { and } \\
2012\end{array}$} \\
\hline $\mathrm{LSDV} \mathrm{R}^{2}$ & & 0.666 & & 0.691 & & 0.663 \\
\hline Within $\mathrm{R}^{2}$ & & 0.178 & & 0.240 & & 0.171 \\
\hline $\mathrm{BIC}$ & & 987.002 & & 1020.535 & & 978.225 \\
\hline AIC & & 831.443 & & 827.939 & & 830.074 \\
\hline
\end{tabular}


Table $4 b$

Estimation of panel regressions with random effects. Dependent variable: Share of national equivalized income attributed to top 3 percentiles. Measure of innovativeness: Patent applications to the EPO by priority year per ten thousand inhabitants

\begin{tabular}{|c|c|c|c|c|c|c|}
\hline \multirow{2}{*}{ Model } & \multicolumn{2}{|c|}{ (1) } & \multicolumn{2}{|c|}{ (2) } & \multicolumn{2}{|c|}{ (3) } \\
\hline & coeff. & st. error & coeff. & st. error & coeff. & st. error \\
\hline patents & -0.365 & 0.227 & $-0.511 * *$ & 0.234 & $-0.537 * * *$ & 0.173 \\
\hline const. & 0.248 & 3.914 & -0.039 & 3.912 & -0.978 & 3.404 \\
\hline GDPpc & 0.004 & 0.018 & 0.014 & 0.018 & & \\
\hline sqGDPpc/1000 & -0.034 & 0.075 & -0.062 & 0.075 & & \\
\hline gov & $-0.099 * *$ & 0.047 & -0.039 & 0.056 & & \\
\hline $\operatorname{tax}$ & 0.001 & 0.012 & -0.009 & 0.012 & & \\
\hline pop_growth & $-0.038^{* * *}$ & 0.014 & $-0.039 * * *$ & 0.014 & $-0.037 * * *$ & 0.013 \\
\hline unemp & $0.081^{* *}$ & 0.035 & $0.098^{* * *}$ & 0.035 & $0.094 * * *$ & 0.033 \\
\hline tert & $0.143^{* * *}$ & 0.039 & $0.127 * * *$ & 0.040 & $0.132^{* * *}$ & 0.037 \\
\hline kaopen & $0.379 * *$ & 0.150 & $0.435^{* * *}$ & 0.151 & $0.414 * * *$ & 0.148 \\
\hline tr_open & $-1.401 * * *$ & 0.313 & $-1.156^{* * *}$ & 0.340 & $-1.120^{* * *}$ & 0.312 \\
\hline infl & $0.069 * *$ & 0.030 & $0.098 * * *$ & 0.037 & $0.089 * * *$ & 0.030 \\
\hline fin $/ 1000$ & $0.351^{* *}$ & 0.150 & $0.307 * *$ & 0.153 & $0.243^{* * *}$ & 0.083 \\
\hline time dummies & \multicolumn{2}{|c|}{ No } & \multicolumn{2}{|c|}{ Yes - all } & \multicolumn{2}{|c|}{$\begin{array}{l}\text { Yes - for years 2010, } 2011 \text { and } \\
2012\end{array}$} \\
\hline Between variance & & 0.720 & & 0.722 & & 0.782 \\
\hline Within variance & & 0.834 & & 0.806 & & 0.820 \\
\hline BIC & & 1031.699 & & 1064.827 & & 1021.287 \\
\hline AIC & & 983.550 & & 983.344 & & 976.8416 \\
\hline
\end{tabular}

Table 4c

Estimation of panel regressions with random effects. Dependent variable: Share of national equivalized income attributed to top 3 percentiles. Measure of innovativeness: the Creative Economy Index

\begin{tabular}{|c|c|c|c|c|c|c|}
\hline \multirow{2}{*}{ Model } & \multicolumn{2}{|c|}{ (1) } & \multicolumn{2}{|c|}{ (2) } & \multicolumn{2}{|c|}{ (3) } \\
\hline & coeff. & st. error & coeff. & st. error & coeff. & st. error \\
\hline CEI & -0.220 & 0.486 & -0.488 & 0.504 & $-0.665 * *$ & 0.309 \\
\hline const. & 0.181 & 4.431 & -0.741 & 4.425 & & \\
\hline GDPpc & -0.005 & 0.023 & 0.011 & 0.024 & & \\
\hline sqGDPpc/1000 & -0.013 & 0.087 & -0.059 & 0.089 & & \\
\hline gov & $-0.111 * *$ & 0.049 & -0.057 & 0.058 & & \\
\hline $\operatorname{tax}$ & 0.000 & 0.013 & -0.012 & 0.013 & & \\
\hline pop_growth & $-0.035^{* *}$ & 0.014 & $-0.035^{* *}$ & 0.014 & $-0.034 * *$ & 0.013 \\
\hline unemp & $0.082^{* *}$ & 0.036 & $0.101 * * *$ & 0.036 & $0.099 * * *$ & 0.034 \\
\hline tert & $0.151^{* * *}$ & 0.041 & $0.138^{* * *}$ & 0.041 & $0.145^{* * *}$ & 0.039 \\
\hline kaopen & $0.359 * *$ & 0.157 & $0.415^{* * *}$ & 0.158 & $0.405^{* * *}$ & 0.154 \\
\hline tr_open & $-1.343^{* * *}$ & 0.337 & $-1.021 * * *$ & 0.371 & $-1.000 * * *$ & 0.331 \\
\hline infl & $0.070 * *$ & 0.030 & $0.102^{* * *}$ & 0.037 & $0.092^{* * *}$ & 0.029 \\
\hline fin/1000 & $0.356^{* *}$ & 0.157 & $0.322^{* *}$ & 0.162 & $0.250^{* * *}$ & 0.091 \\
\hline time dummies & \multicolumn{2}{|c|}{ No } & \multicolumn{2}{|c|}{ Yes - all } & \multicolumn{2}{|c|}{$\begin{array}{l}\text { Yes - for years 2010, } 2011 \text { and } \\
\qquad 2012\end{array}$} \\
\hline Between variance & & 1.003 & & 1.005 & & 1.025 \\
\hline Within variance & & 0.833 & & 0.805 & & 0.815 \\
\hline $\mathrm{BIC}$ & & 1060.394 & & 1098.142 & & 1058.620 \\
\hline $\mathrm{AIC}$ & & 1012.245 & & 1016.658 & & 1014.175 \\
\hline
\end{tabular}


Table $5 \mathrm{a}$

Estimation of panel regressions with fixed effects. Dependent variable: Share of national equivalized income attributed to top 1 percentile. Measure of innovativeness: Gross domestic expenditure on R\&D as a percentage of GDP

\begin{tabular}{|c|c|c|c|c|c|c|}
\hline \multirow{2}{*}{ Model } & \multicolumn{2}{|c|}{ (1) } & \multicolumn{2}{|c|}{ (2) } & \multicolumn{2}{|c|}{ (3) } \\
\hline & coeff. & st. error & coeff. & st. error & coeff. & st. error \\
\hline gerd & 0.478 & 0.296 & $0.609 * * *$ & 0.217 & 0.323 & 0.274 \\
\hline const. & 0.481 & 4.603 & 0.404 & 4.778 & -2.683 & 5.097 \\
\hline GDPpc & $-0.045^{*}$ & 0.027 & -0.032 & 0.027 & & \\
\hline sqGDPpc/1000 & 0.106 & 0.122 & 0.087 & 0.113 & & \\
\hline gov & $-0.167 * *$ & 0.078 & -0.115 & 0.074 & & \\
\hline $\operatorname{tax}$ & -0.011 & 0.011 & -0.034 & 0.021 & $-0.026^{*}$ & 0.015 \\
\hline pop_growth & -0.019 & 0.017 & -0.018 & 0.017 & & \\
\hline unemp & $0.060^{* *}$ & 0.028 & $0.069 * * *$ & 0.026 & $0.092^{* * *}$ & 0.029 \\
\hline tert & $0.135^{* * *}$ & 0.033 & $0.110^{* *}$ & 0.048 & $0.088^{*}$ & 0.053 \\
\hline kaopen & 0.129 & 0.152 & 0.134 & 0.124 & & \\
\hline tr_open & $-1.385^{*}$ & 0.720 & -0.534 & 0.865 & & \\
\hline infl & 0.043 & 0.026 & $0.065^{* *}$ & 0.028 & $0.074 * * *$ & 0.024 \\
\hline fin/1000 & $0.318^{* *}$ & 0.151 & $0.293^{* *}$ & 0.147 & $0.177^{*}$ & 0.098 \\
\hline time dummies & \multicolumn{2}{|c|}{ No } & \multicolumn{2}{|c|}{ Yes - all } & \multicolumn{2}{|c|}{ Yes - for years 2008, 2010-2014 } \\
\hline $\mathrm{LSDV} \mathrm{R}^{2}$ & & 0.500 & & 0.532 & & 0.504 \\
\hline Within $\mathrm{R}^{2}$ & & 0.144 & & 0.198 & & 0.150 \\
\hline BIC & & 884.448 & & 916.138 & & 882.302 \\
\hline AIC & & 728.889 & & 727.245 & & 726.743 \\
\hline
\end{tabular}

Table 5b

Estimation of panel regressions with random effects. Dependent variable: Share of national equivalized income attributed to top 1 percentile. Measure of innovativeness: Patent applications to the EPO by priority year per ten thousand inhabitants

\begin{tabular}{|c|c|c|c|c|c|c|}
\hline \multirow{2}{*}{ Model } & \multicolumn{2}{|c|}{ (1) } & \multicolumn{2}{|c|}{ (2) } & \multicolumn{2}{|c|}{ (3) } \\
\hline & coeff. & st. error & coeff. & st. error & coeff. & st. error \\
\hline patents & -0.190 & 0.172 & -0.283 & 0.176 & $-0.218^{*}$ & 0.121 \\
\hline const. & -1.281 & 3.148 & -0.874 & 3.138 & -1.649 & 2.697 \\
\hline GDPpc & 0.014 & 0.014 & 0.022 & 0.014 & & \\
\hline sqGDPpc/1000 & -0.053 & 0.058 & -0.077 & 0.058 & & \\
\hline gov & $-0.072 *$ & 0.038 & -0.026 & 0.043 & & \\
\hline $\operatorname{tax}$ & -0.001 & 0.009 & -0.011 & 0.009 & & \\
\hline pop_growth & -0.018 & 0.011 & $-0.019 *$ & 0.011 & & \\
\hline unemp & $0.053^{*}$ & 0.029 & $0.068^{* *}$ & 0.029 & $0.075^{* * *}$ & 0.024 \\
\hline tert & $0.085^{* * *}$ & 0.032 & $0.066^{* *}$ & 0.032 & $0.076^{* *}$ & 0.030 \\
\hline kaopen & $0.204 *$ & 0.118 & $0.235^{* *}$ & 0.119 & $0.208^{*}$ & 0.113 \\
\hline tr_open & $-0.991 * * *$ & 0.238 & $-0.749 * * *$ & 0.254 & $-0.775^{* * *}$ & 0.224 \\
\hline infl & $0.049^{*}$ & 0.025 & $0.063 * *$ & 0.031 & $0.065^{* * *}$ & 0.024 \\
\hline fin/1000 & $0.226^{*}$ & 0.117 & 0.191 & 0.119 & $0.145^{* *}$ & 0.057 \\
\hline time dummies & \multicolumn{2}{|c|}{ No } & \multicolumn{2}{|c|}{ Yes - all } & \multicolumn{2}{|c|}{$\begin{array}{l}\text { Yes - for years 2010, } 2011 \text { and } \\
2012\end{array}$} \\
\hline Between variance & & 0.351 & & 0.353 & & 0.319 \\
\hline Within variance & & 0.591 & & 0.578 & & 0.591 \\
\hline BIC & & 879.807 & & 906.267 & & 861.266 \\
\hline AIC & & 831.658 & & 824.784 & & 820.524 \\
\hline
\end{tabular}


Table $5 \mathrm{c}$

Estimation of panel regressions with random effects. Dependent variable: Share of national equivalized income attributed to top 1 percentile. Measure of innovativeness: the Creative Economy Index

\begin{tabular}{|c|c|c|c|c|c|c|}
\hline \multirow{2}{*}{ Model } & \multicolumn{2}{|c|}{ (1) } & \multicolumn{2}{|c|}{ (2) } & \multicolumn{2}{|c|}{ (3) } \\
\hline & coeff. & st. error & coeff. & st. error & coeff. & st. error \\
\hline CEI & 0.070 & 0.365 & $\begin{array}{l}-0.182 \\
\end{array}$ & 0.376 & -0.112 & 0.202 \\
\hline const. & -0.437 & 3.572 & -0.847 & 3.558 & -0.727 & 2.697 \\
\hline GDPpc & 0.005 & 0.018 & 0.019 & 0.018 & & \\
\hline sqGDPpc/1000 & -0.034 & 0.067 & -0.075 & 0.068 & & \\
\hline gov & $-0.088^{* *}$ & 0.039 & -0.043 & 0.045 & & \\
\hline $\operatorname{tax}$ & -0.002 & 0.009 & -0.012 & 0.010 & & \\
\hline pop_growth & -0.015 & 0.011 & -0.016 & 0.011 & & \\
\hline unemp & $0.055^{*}$ & 0.029 & $0.071^{* *}$ & 0.029 & $0.067^{* * *}$ & 0.024 \\
\hline tert & $0.085^{* *}$ & 0.033 & $0.070^{* *}$ & 0.033 & $0.068^{* *}$ & 0.030 \\
\hline kaopen & 0.181 & 0.122 & $0.217^{*}$ & 0.123 & & \\
\hline tr_open & $-0.994 * * *$ & 0.249 & $-0.707 * * *$ & 0.267 & $-0.724 * * *$ & 0.232 \\
\hline infl & $0.050^{* *}$ & 0.025 & $0.066^{* *}$ & 0.031 & $0.063^{* * *}$ & 0.024 \\
\hline fin/1000 & $0.235^{*}$ & 0.121 & $0.207 *$ & 0.124 & $0.138^{* *}$ & 0.061 \\
\hline time dummies & \multicolumn{2}{|c|}{ No } & \multicolumn{2}{|c|}{ Yes - all } & \multicolumn{2}{|c|}{$\begin{array}{l}\text { Yes - for years 2010, } 2011 \text { and } \\
2012\end{array}$} \\
\hline Between variance & & 0.420 & & 0.421 & & 0.368 \\
\hline Within variance & & 0.590 & & 0.577 & & 0.590 \\
\hline BIC & & 893.776 & & 921.892 & & 875.034 \\
\hline AIC & & 845.627 & & 840.409 & & 837.996 \\
\hline
\end{tabular}

Note: In all tables stars indicate significance level: $* * *<0.01, * *<0.05, *<0.1$. For fixed effects models robust standard errors are reported (HAC).

Source: Author's calculation using gretl software. 